\title{
PKD1L1 Gene
}

National Cancer Institute

\section{Source}

National Cancer Institute. PKD1L1 Gene. NCI Thesaurus. Code C114553.

This gene is involved in the modulation of calcium transport. 